Manuscript received: 18.08.2021

Accepted: 30.08 .2021

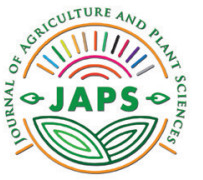

\author{
In print: ISSN 2545-4447 \\ On line: ISSN 2545-4455 \\ doi: https://doi.org/10.46763/JAPS21192047t \\ Original scientific paper
}

\title{
THE ROLE AND IMPORTANCE OF AGROBIODIVERSITY FOR AGRICULTURE
}

\author{
Fidanka Trajkova ${ }^{*}$, Sasho Arsov' ${ }^{1}$, Liljana Koleva Gudeva' \\ 'Faculty of Agriculture, Goce Delcev University - Stip, Krste Misirkov, 10-A, 2000 Stip, Republic of North Macedonia \\ *Corresponding author: fidanka.trajkova@ugd.edu.mk
}

\begin{abstract}
Biodiversity and agriculture have an inseparable relationship, with interdependent interactions between their constituent components. Agriculture as a basic anthropogenic activity is one of the main factors in the directions of development in biodiversity. Agrobiodiversity is the basis of the existence of food production processes and provides and secures many essential aspects of modern living. Many of these processes are completely unknown, and some of them we are not even aware that they are a consequence of the biological activity of various organisms. Thus, biodiversity provides food, clean drinking water, energy, raw materials for industry, tourism and recreational opportunities, scientific research, and medicine. If agricultural practices that promote biodiversity are used, such as: crop rotation, cover crops, buffer zones, use of biopesticides, beneficial insects and intercrops, then natural processes in soil, plants and environment are significantly intensified for the benefit of farmers, plants and the overall environment. On the other hand, if techniques and methods that reduce biodiversity are applied in the agroecosystem and its environment, such as fertilizers, chemical pesticides, hormones, intensive processing, monoculture and others, processes of reduction, disappearance and pollution of the environment and the overall biodiversity occur. Therefore, careful selection of agricultural practices is needed that would not jeopardize the survival of the species, and at the same time high yields with good quality will be achieved.

The aim of this review paper is to present up to date relationship between biodiversity and agriculture and to highlight current issues of biodiversity loss and methods for its conservation.
\end{abstract}

Keywords: genetic resources, indigenous varieties, agrobiodiversity, organic production, sustainable agriculture, protection, conservation

\section{INTRODUCTION}

There are many different definitions of agrobiodiversity, but they all describe the variability of many plants, animals and microorganisms that are directly or indirectly involved in the production of food, textiles, fuels, pharmaceuticals, fodder, forestry, aquaculture and livestock, but also microorganisms, insects or animals involved in an agroecosystem such as predators, pollinators or soil microorganisms that have a beneficial effect on crops growth (Brookfield \& Stocking, 1999).

Agrobiodiversity can be defined as an interaction between genetic resources, the environment and the practices undertaken by a group of different people, so managing water and soil as resources are quite different. Therefore, agrobiodiversity covers a wide range of animals, plants and microorganisms that are essential for sustainable agroecosystems (FAO, 2005).

Agrobiodiversity is a result of natural selection, but also many years of careful inadvertent selection of good and healthy plants and animals by farmers and ranchers (FAO, 2005). Farmers have seen by experience that only the best species survive and each year from their yields they keep only seeds with the best characteristics and highest quality for the next sowing or the healthiest animals for reproduction. Thus, according to FAO (2005) agrogenetic resources include:

1. Post-harvest residues of certain crops, animal species, wild plant species and 
wild-caught animals.

2. Species that support the food production process such as soil microorganisms, pollinators, predators and other insects and animals.

3. The wider environment in which agroecosystems are located, that also has an impact on food production.

When we talk about agrobiodiversity, we should distinguish it from the term biodiversity which is a much broader term and includes agrobiodiversity itself. Biodiversity tells us about the overall variability of all living organisms that can be found on planet Earth. While agrobiodiversity includes only those organisms that are involved in agricultural production and food production (Fig. 1).

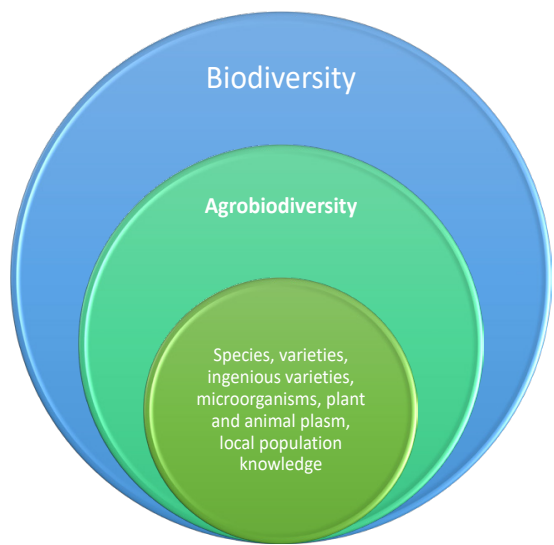

Figure 1. The components of biodiversity.

According to the Ecological Society of America agrobiodiversity could be divided into 3 interrelated levels (Fig. 2):

1. Genetic agrobiodiversity - includes all domesticated species and their wild relatives used in agriculture. It includes all newly created man-made varieties and animals. It includes wild species that are a significant source of genetic variability.

2. Species agrobiodiversity - includes all species whether wild or domesticated that are dependent on agricultural practices.

3. Agroecosystem variability - includes the ecological habitats of plants, animals and microorganisms that fit in time and space, at the level of farm, field or relief.

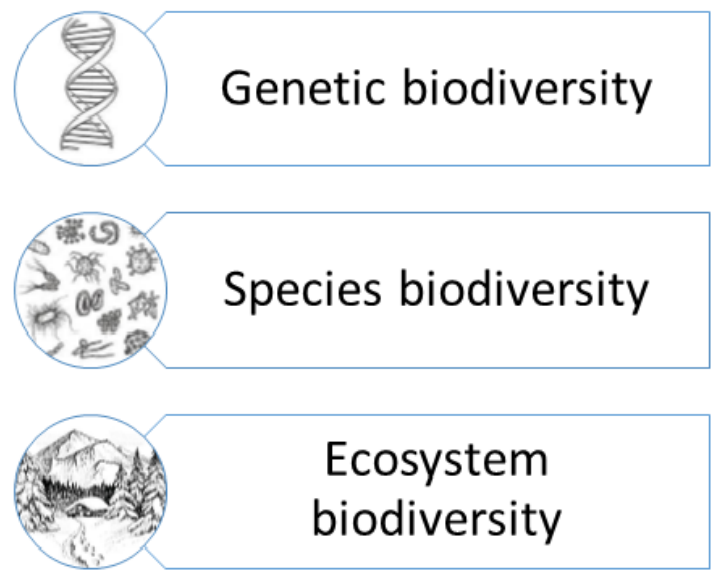

Figure 2. Three different levels of agrobiodiversity division.

\section{Genetic resources as part of agrobiodiversity}

All the diversity in the ecosystem is delivered from genetic resources. Genetic resources could be defined as a source of genetic variability. Total genetic material or all alleles from different genes present in cultivars and other wildlife is called plant genetic resources. 
Plant genetic resources are once again called plant germplasm, gene pool or genetic reserve. Germplasm is a seed or other plant reproductive material, such as a leaf, stem, root, pollen, cell culture, DNA, from which it can be made as a mature plant. It is any kind of genetic material that can be used to protect the species and the populations. In the genetic sense of germplasm, a substance is felt in the cell nucleus, which determines the following properties of the organism and transmits their characteristics to future generations. Germplasm has not only reproductive value, but also with the selection and breeding can be improved and used to improve other crops and obtain new varieties (llieva, 2012). A variety could be defined as group of plants within a species, recognized for some improved features, that are retained after reproduction.

Ilieva (2012)according to origin of cultivated plants found in certain agroecosystem, divides them into four groups: indigenous species, introduced species, wild species, and breeding material (Fig. 3).

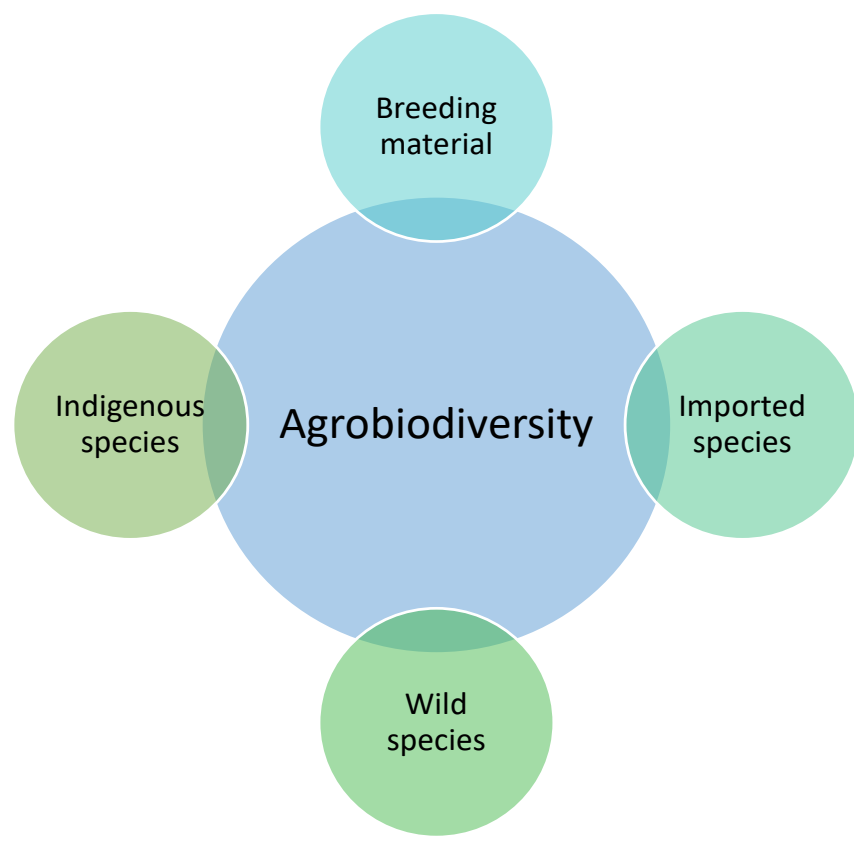

Figure 3. Agrobiodiversity's plant components.

\section{Contribution of the biodiversity to agriculture}

Agriculture represents a basic source of food for humans and animals as well as one of the main sources of raw materials for the textile, pharmaceutical and leather industries. The great diversity of our diet would not be possible without biodiversity. Biodiversity is the result of continuous evolution of plants and animals (Dudley \& Alexander, 2017). The life we live would not be the same if the evolution of animals and plants did not take place in the direction in which it has taken place to this day. The large selection of crops contributes to the health and well-being of people through the various nutritional values that cultures possess. Biodiversity is the basis of agriculture. Its existence is crucial for the production of food and other agricultural goods, the benefits of which provide food, nutritional value and human well-being. Biodiversity is also the basis for the existence of all plant and animal species and their varieties (Convention on Biological Diversity, 2008).

According to the Convention on Biological Diversity (2008), services and benefits of biodiversity are:

1. Direct services - food, fuels, textile fibres, biochemicals, fresh water and genetic resources.

2. Regulatory services - flood protection, erosion control, pollination, pest control, climate impact and disease.

3. Cultural services - knowledge of farmers, profession, education, recreational services, cultural and religious values, inspiration. 
4. Support to other processes - water cycle, nutrient cycle, primary production, provide habitat and atmospheric oxygen.

Apart from offering ecological and nutritional security through biodiversity, agriculture is also an important driver of socio-economic circumstances in society, with many people their main occupation being agriculture. The global agricultural workforce represents 1.3 billion people, agriculture is their main occupation. It represents $22 \%$ of the total population of the planet and $46 \%$ of the total working-age population (Harris, 2001). According to Bélanger \& Pilling (2019) 7,000 out of approximately 24,000 known higher plants are directly involved in agriculture. Nevertheless, this distribution is not equal as out of these 7,000 plants only 30 plant species account for $90 \%$ of total agricultural production. Corn, wheat, rice, potatoes provide half of the total necessary nutrition of mankind. The situation is no different in the animal world, where out of 15,000 known mammals and birds, only 30-40 animals are domesticated, and 14 of them including chickens, cattle, pigs, sheep and goats occupy $90 \%$ of all domestic animals. That is the reason for huge genetic erosion in the last decades (Bélanger \& Pilling, 2019).

\section{Agriculture influence on biodiversity reduction}

According to the Convention on Biological Diversity (2008), agriculture reduces biodiversity through the following practices:

\section{Crop production}

Intensive agricultural practices contribute to the reduction of biodiversity (Benton et al., 2003). Lack of crop rotation and cultivation in monoculture is one of those reasons. The use of pesticides and mineral fertilizers reduces soil biodiversity, destroying some important microorganisms and pollinators. Drainage systems and intensive tillage homogenize the fields and lead to a lack of diversity in ecosystems. Encouraging hybrids and superior varieties neglects the indigenous varieties, while the destruction of forests, swamps and meadows contributes to the loss of local flora and fauna.

\section{Livestock production}

Modern livestock production emphasizes animal yields rather than animal welfare. Nowadays intensive livestock farming is in stables where the animals are provided with constant access to water and selected food that stimulates them to produce more meat, milk or eggs. Increasingly, high-yielding breeds are being bred to replace indigenous and local domestic animals.

Biodiversity increases the resistance of plants to stressful conditions, provides an opportunity to adapt to adverse challenges and it is a key factor in increasing intake and reducing output in sustainable agricultural production (Isbell et al., 2015). The trend of increasing world population puts additional pressure on agricultural production to obtain higher yields, but at the same time restrictions on the use of chemical pesticides, fertilizers and lack of land appear as another limiting factor (Pimentel et al., 1997). All these facts pose a series of questions about how food and other ecosystem services would be provided without disrupting natural flows in nature. Therefore, biodiversity proves to be extremely important in terms of contributing genetic resources, pollinators, predators and microorganisms, if intensively involved in production, could replace some of currently used raw materials.

\section{Biodiversity and soil fertility}

All microorganisms such as bacteria, protozoa, worms, mice, insects, larvae, algae and fungi are components of biodiversity. Soil is a living substance that is home to thousands of micro- and macroorganisms, as well it is a basis for plant production (Giller et al., 1997). The number of micro and macroorganisms in the soil depends on soil type, location, presence of organic matter and climatic conditions (Petersen \& Luxen, 1982; Koleva Gudeva et al., 2012). Most microorganisms are present in soils with high content of organic matter. The pedosphere is one of the richest with organisms, often up to 2-3 billion microorganisms can be found in 1 gram of soil. The number of microorganisms is referred to as soil biogenicity. Soil fertility and biogenicity are interrelated. Soils with higher biogenicity are also characterized by higher fertility (Hasan, 2000). The application of appropriate agrotechnical and land management measures can increase the number of organisms in the soil, but also harm them.

Soil microorganisms are also crucial in the chemical change of soil and the transformation 
of minerals, with the secretion of various organic acids that act on the soil minerals. For example, certain bacteria attack the highly resistant silicates, such as kaolinite, and break them down. They also act on some hard-todissolve fertilizers (Rodriguez \& Fraga, 1999). Microorganisms play an important role in the oxidation and reduction of nitrogen, sulfur, iron and manganese minerals. With the help of nitrifying bacteria, $\mathrm{NH}_{4}^{+}$turns into $\mathrm{NO}^{2-}$ and then $\mathrm{NO}^{3-}$ a process called nitrification.

\section{Biodiversity and plant pollination}

Pollination of flowers can be done by wind or by animals such as insects, birds and bats. Insect pollination is essential for many plants (Fig. 4). Crops of the Rosaceae family are pollinated by insects. The most common insect pollinators in agricultural systems are honeybees represented with 20,000 species (Delaplane et al., 2000). Wasps, moths, butterflies, and beetles can also serve as pollinators (Rader et al., 2016). In addition to honeybees, there are other types of pollinators, such as beetles, which are bred and sold for successful pollination. Vertebrate pollinators include bats, monkeys, rodents, squirrels, lemurs, etc.

Pollination by insects and other animals provides us healthy and safe food, increases yield, enriches biodiversity, maintains ecosystems and ensures the survival of over $75 \%$ of plant species.

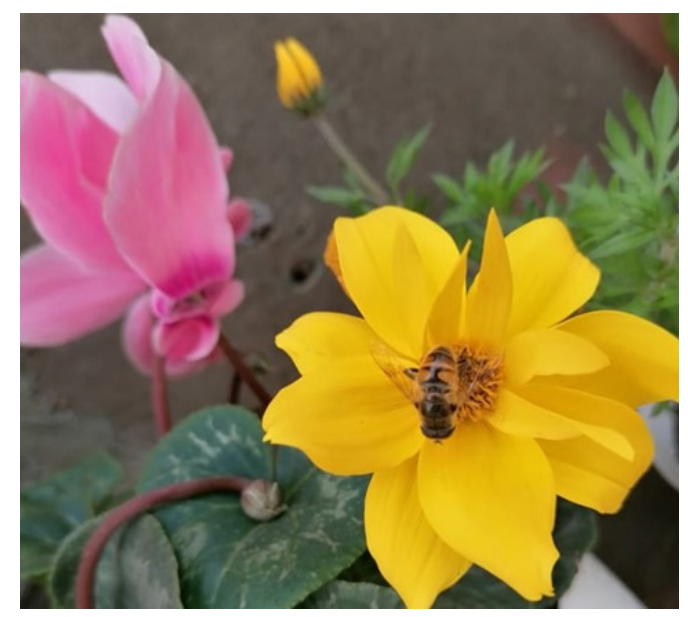

Figure 4. Insect pollinator (photo: Saso Arsov).

\section{Biodiversity and the fight against insects and diseases}

Modern agricultural production is almost unimaginable without the use of chemicals that help farmers in fight with diseases and pests (Mellon et al., 2001). But nature itself has its own mechanisms of elimination of the most common pathogens. The existence of biodiversity in agro-ecosystems optimizes the fight against weeds, diseases and pests. There are beneficial insects that feed on certain insects, such as ladybugs that feed with aphids (Francis et al., 2001). Insects are one of the most common and diverse organisms in the environment. More than a million different species of insects are described worldwide, and about 10,000 new species are described each year. The vast majority of insects are beneficial or neutral to crop production - less than $1 \%$ of known insect species are considered pests (Stork, 2018).
Some plant-eating insects reach harmful levels only under special conditions, while others are well-adapted to tolerate or exploit certain crops or crop production systems and can regularly cause economic losses. Understanding the environmental principles underlying insect population dynamics and community population interactions can help organic producers manage their farm insects, both pests and beneficial species, to prevent or reduce crop losses (Pal \& McSpadden, 2006). The insect populations are dynamic, the number of individuals in a population can change on daily, seasonal and yearly basis as a result of interactions with the environment. The environment itself is changeable and can provide different availability of the resources that insects need to survive. The number of resources available can affect the size that an insect population can achieve (Khaliq et al., 2014). This concept is sometimes referred to 
as the carrying capacity of the environment (Schowalter, 2019). Growing unwanted crops by rotation or resistant varieties and preserving natural enemies combines factors to reduce pest populations or promote the attraction of beneficial insects.

\section{Other benefits of agrobiodiversity}

According to Koleva Gudeva et al. (2012), other benefits of agrobiodiversity are: provision of medicines, wood products, diversity of the nature, protection of resources, climate impact, provision of genetic resources, tourist opportunities and scientific research.

In addition to the numerous benefits of agriculture, biodiversity is an essential component in many other industries and elements of human life (Institute of Biodiversity Conservation, 2005). The variety and abundance of medicinal plants open a new door for the pharmaceutical industry where most of the medicines are derived from plants. Biodiversity affects the microclimate of an environment, but also the macroclimate. The presence of forest strips makes the air pleasant and protects us from soil erosion. Forests are also the primary resource for the wood industry from which are made products such as furniture, firewood, building materials, art, etc. Ecosystem biodiversity has been used for several scientific studies that contribute to a better understanding of processes in nature and gives us answers for some long-standing questions. Biodiversity is a unique opportunity to attract tourists and visitors who admire the scenic views of nature and the diversity of plants, animals, and relief formations. However, all these industries harm biodiversity if resources are not used sustainably.

\section{Agrobiodiversity and the organic production}

Unlike the conventional farming systems, organic agroecosystems can use pesticides only as a last option and only limited non-synthetic or synthetic materials. Organic producers need to adapt practices which "maintain or enforce natural resource of work, including soil and water quality" (USDA, 2000). Environmental consideration of insects, especially their biology and interactions with plants, other organisms, and the environment, is essential to design a successful organic farm. The environmental understanding of the insects helps an organic farmer can develop a farm plan that can be used to reduce the risk of insects to reach the economic level of damage, identify them, and also use them as beneficial for different kind of agricultural services. Successful organic farm management has used the environmental knowledge of insects to recruit them as allies in terms of maintaining and preventing their natural resource base and reducing the chances of them becoming harmful (Culliney \& Pimentel, 1986).

Each type of soil organism occupies a different sequence in the food chains and favours a different source of substrate and nutrients. Many organisms in the soil rely on the organic matter. A rich supply of diverse source of organic matter generally supports presence of wider spectre of organisms (Gomiero et al., 2011). It is highly recommended mixing and change of spatial-temporal distribution of plant species and varieties for creation of various resources that will stimulate soil biodiversity. Different habitats support complex mixtures of the organisms and through crop rotation or intercropping, different organisms may be present in the soil and their presence can support different processes: improvement of nutrient transport, natural processes for control of harmful organisms, improvement of soil fertility etc. (Watson et al., 2002). Soil biodiversity activity can be stimulated by improving the living conditions in soil, such as improving the aeration, suitable temperature, and quantity and quality of nutrients. In this regard, care should be taken to reduce tillage, minimize soil compaction and reduce chemical utilization.

Organic production is a great example of the symbiosis between modern agricultural production and the use of biodiversity. Organic production is based on the principle that integrates biodiversity and cares about the environment. It has a holistic approach to the overall ecosystem and respects natural flows in nature (Underwood et al., 2011). Thus, organic production requires a variety of techniques that promote and maintain biodiversity, such as intercropping, use of animal and green manure, use of biopesticides and biological control, companion plants, reduced soil treatment, buffer strips, etc. 


\section{Agrobiodiversity as an opportunity to save the yield}

Agricultural production today is reduced to growing new high-yielding varieties that are in demand in the market (Frankel \& Soule, 1981). Therefore, in one region can happen only one or two varieties of a certain crop to be grown. This increases the risk of losing yields, because that variety, despite all the good features, probably has a weakness in certain environmental conditions. Thus, the loss of the yield of that dominant variety in a certain vegetation year as a consequence of various factors would mean the loss of the full yield. Hence, the existence of divergence would somehow ensure farmers' work. Possession of indigenous crop populations on fields would mean possession of varieties resistant and adapted to the microclimate (Vasić et al., 2013). They are product of natural long-term selection that has taken place continuously in the same area (Cleveland et al., 1994). Thus, these varieties have the best resistance to climatic factors that occur in that region, but also to sporadic pathogens. On the other hand, their feature is the poor- and low-quality yield that does not meet the needs and tastes of the modern consumer. It is important to note that yields in local populations are low but quite stable, especially in critical environmental conditions.

Local varieties are characterized by specificity for only one specific region, and they have high heterogeneity. Their heterogeneity is often used by breeders to enhance an existing variety that lacks some quality. They are characterized by high plasticity and tolerance. They are resistant to lodging, low and high temperatures, pathogens, etc., but the main reason for their avoidance in commercial production are the low yields. Consequently, many species have been either completely lost or lost for local utilization (Jarvis et al., 2011).

\section{Agricultural practices to promote biodiversity}

Promoting agricultural practices that include greater biodiversity in agroecosystems would require radical changes in current agricultural production. Intensive agricultural production is reduced to great homogeneity in terms of assortment, relief landscape, uniform and depleted soil, dependence on fertilizer application, and mandatory application of pesticides (Dudley \& Alexander, 2017). The education of farmers shall play a key role in transformation of this situation, as well as their financing. Application of the following practices significantly contributes to increasing biodiversity in agroecosystems:

- crop rotation

- sideration

- biocontrol

- selection of suitable variety

- animal manure application

- cover plants

- buffer strips

1. Crop rotation represents the rotation of crops in time and place, as opposed to monoculture. This would mean that the same crop should not be sown on the same plot for several years in a row. The benefits of crop rotation are well known, certain weeds, diseases, and insects are eliminated, yields are increased, plants make optimal use of soil nutrients, and cultivation of certain crops such as plants of the family Fabaceae increases the content of readily available soil nitrogen (Mihajlov, 2013). Crop rotation significantly affects not only the yield but also the agrobiodiversity in the soil and the attraction of various insects.

2. Sideration or green manure is the cultivation of legumes or other crops that enrich the soil with organic matter and necessary nutrients. These plants are grown until the moment of their flowering and then incorporated in the soil. Their presence not only increases the content of organic matter and nutrients in the soil but also encourages microbial interaction in the soil (Underwood \& Tucker, 2016). Soil processes associated with plant used for green manure are related to the decomposition of plant residues into organic matter and the nitrogen-fixing processes in legumes. Growing plants as green manure also attracts a variety of beneficial insects.

3. Phytopathology and entomology use the term biocontrol to refer to the use of antagonistic microorganisms or insects to reduce the number of suitable hosts such as weeds, insects, or pathogens. In a broader sense, the term also refers to the secretions obtained from certain organisms which, if 
applied to a suitable undesirable organism in a certain plot, have an antagonistic relationship. Throughout their life cycle, plants and pathogens interact with a wide range of organisms. These interactions can significantly affect plant health in a variety of ways. To understand the mechanisms of biological control, it is useful to evaluate the different ways in which organisms interact. Organisms must have some form of direct or indirect contact. Odum \& Kuenzler (1955) proposed that the interactions of two populations can be defined according to the results obtained for each. The types of interactions are named reciprocity, commensalism, neutralism, competition, amensalism, parasitism, and predation. While the terminology has been developed for macroecology, examples of all these types of interactions can be found in the nature at both the macroscopic and microscopic levels. Because the development of plant diseases involves both plants and microbes, the interactions that lead to biological control take place on multiple levels. From a plant point of view, biological control can be considered as a net positive result resulting from various specific and non-specific interactions. Using the spectrum of Odom concepts, we can begin to classify and functionally differentiate the various components of ecosystems that contribute to biocontrol. Mutualism is an association between two or more species where both species benefit. Sometimes, it is a mandatory lifelong interaction that involves close physical and biochemical contact, such as those between plants and mycorrhizal fungi. However, they are generally optional and opportunistic. For example, bacteria of the genus Rhizobium can reproduce either in the soil or, to a much greater extent, by their interconnection with leguminous plants. These types of interdependence can contribute to biological control by strengthening the plant with improved nutrition and/or by stimulating the host's defences. Protocooperation is a form of interdependence, but the organisms involved do not depend solely on each other to survive. Other examples of biological control are the cover crops used to attract natural predators to pests by providing elements of their habitat. This is a form of biological control known as habitat enhancement but achieved using cover crops. Findings on the relationship between crop presence and predator/pest population dynamics are mixed, indicating the need for detailed information on specific crop types and management practices to best complement the given integrated pest management strategy.

4. Selection of suitable plant varieties and animal breeds increases and promotes biodiversity. According to Mazid \& Khan (2015), the use of a suitable variety increases the yield by $10-35 \%$. If cultivated varieties are appropriate for the region of cultivation, there are economic and environmental benefits. Cultivation of suitable varieties and crops reduces costs for pesticides, fertilizers, and soil treatment, thus contributes to a cleaner environment. A clean environment is one of the preconditions for better biodiversity.

5. The use of animal manure contributes to the enrichment of the soil with various nutrients that are important for plant growth and development (Fig. 5). Another more important feature of manure is that they influence the texture of the soil and enrich it with organic matter (Darwish et al., 1995). In intensive agricultural production, it is recommended to apply manure once in three years, while in organic farming it is applied almost every year due to the limited access to synthetic fertilizers. Animal manure is added to encourage the living organisms in the soil and to perform various interactions and decomposition processes. Microorganisms transform the elements in manure and make them easily available for uptake by plants through the root system (Henis, 1986). The indirect value of animal manure for biodiversity is the reduction of applied synthetic fertilizers which have negative impact on soil biodiversity, pollute groundwater and have a potentially harmful effect on plants and humans. 


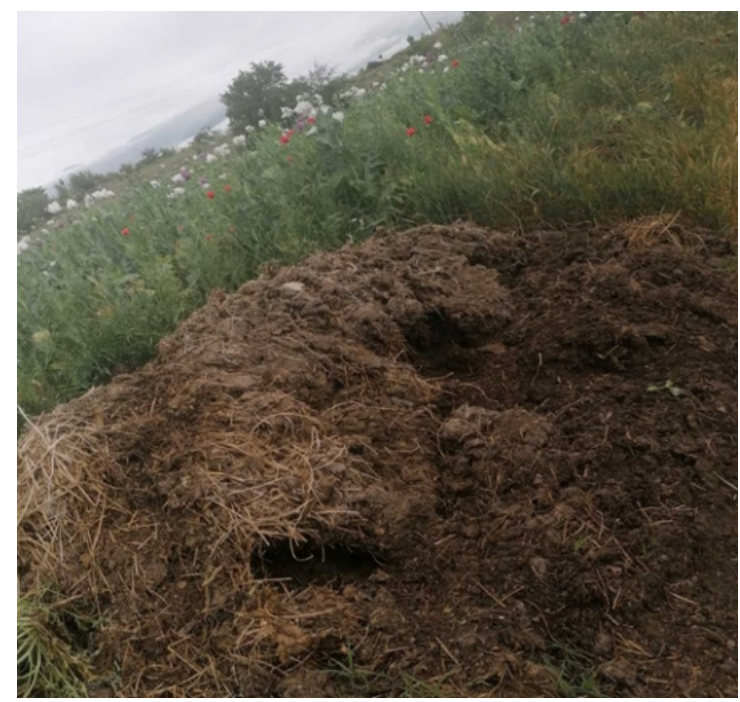

Figure 5. Animal manure (photo: Sasho Arov).

6. Cover crops are commonly used agricultural practice. These are plants that are sown on the agricultural fields before, after, or together with the main crop. These crops have many beneficial effects for both farmers and the environment such as erosion control, soil fertility conservation, water quality, pest and disease control, biodiversity, and wildlife. Most often, cover plants are not crops of economic importance and their management is not intensive, so they create favourable conditions for biodiversity development (Snapp et al., 2005). Combining cover plants with a suitable crop rotation creates ideal conditions for the development of very complex biodiversity in agricultural fields. In a study by Price et al. (2008), researchers compared the composition of insect species and sparrows between conventional and cotton fields, where cover crops had previously been used in the southern United States. Cotton fields and cotton fields with clover as cover crop, left to grow between the cotton rows during the early cotton growing season were sown for experimental purpose. During the migration season, they found that insect densities were 7 to 20 times higher in cotton fields with clover cover culture than in conventional cotton fields. Other examples of cover crops are nematoderesistant white mustard (Sinapis alba L.) and radish (Raphanus sativus L.) where the nematode population is significantly reduced, by $70-99 \%$, depending on the species and time of cultivation (Hossain et al., 2015).

7. Buffer belts are primarily used for protection against soil erosion (Barling \& Moore, 1994). These are usually long strips of perennial trees planted in large valleys where wind erosion often occurs. Trees can be of different types and varieties, but they are usually deciduous. In addition to erosion protection, buffer belts are also recommended in organic farming to protect crops from the adverse effects of chemical reagents used nearby. With the help of the wind, pesticides are easily transferred to wider distances. Buffer belts are home to several micro and macroorganisms with beneficial effects on the agroecosystems (Ma et al., 2002). In our country, tree protection zones are used in Ovce Pole, as protection of the soil from wind erosion and damage to cereal crops.

\section{Loss of biodiversity}

Biodiversity loss can be defined as a decrease in the number of individuals of a particular species or the permanent extinction of a particular species. The loss of biodiversity does not directly affect only the organisms that inhabit a certain area, but also certain habitats, landscapes, and loss of genetic variability.

When we talk about the loss of genetic variability, we come to the term genetic erosion, which refers to the disappearance of a certain gene or allele, and sometimes this 
term describes the complete loss of a certain species. Genetic erosion occurs as a result of the disappearance or inability of one parent to mate in a population of rare endemic species. In such small, almost homogeneous populations of organisms, genetic variability is reduced to minimal genetic differences and inbreeding depression is very common. Inbreeding is known to reduce biological viability and may lead to extinction. In agriculture, genetic erosion refers to the loss of certain alleles and complexes of genes such as those found in indigenous populations that are associated with high adaptability to the conditions of the environment from which they originate (Maxted \& Guarino, 2006). The main factor for the loss of these varieties is their replacement with more productive varieties, legal decisions, change of the agricultural system, overuse, degradation of the environment. Cultivation of introduced varieties has the greatest implications in the process of extinction. In the case of loss of domestic breeds of animals, usual reasons are use of exotic crossings, weak government conservation laws, neglect of certain breeds due to low profitability, intensive production, lack of proper animal disease management, lack of sufficient pastures, and other elements required by the environment, lack of control of inbreeding and carelessness in selection processes with rare breeds. Another increasingly common term in this context is "genetic pollution" and it refers to the transmission of pollen, and consequently the genes from genetically engineered plants to their wild relatives (Meilink et al., 2015).

The main causes of biodiversity loss are pollution, habitat loss, overuse, climate change, natural disasters, hunting, and introduction of invasive species (Fig. 6).

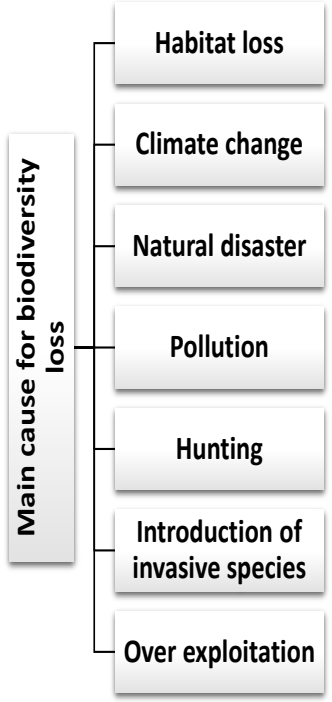

Figure 6. The main causes of biodiversity loss (adapted from Singh et. al., 2021).

According to Singh et al. (2021), the biggest causes of biodiversity loss are:

1. Habitat loss - A major threat to biodiversity and species survival is habitat loss. This is a serious issue for both wildlife and humans. Habitat and wildlife are interconnected. Habitat destruction, degradation, and fragmentation are the three dominant categories of habitat loss. Habitat destruction is the mass extinction of a species of their natural habitat, making it incapable of supporting domestic ecosystems and species. The development of agricultural practices, reduced resources such as food, water, air quality, mining, pollution, logging, catastrophic fishing activities, activities related to urbanization, and interruption of ecosystem-related processes are the dominant elements of habitat degradation. Habitat degradation affects both habitat species and humans. Erosion, nutrient depletion, and desertification cause further degraded soil loss. Habitat fragmentation is another gigantic issue that arises because of human development activities. These fragmented 
areas disrupt the habitats of animal and plant species, isolate animal communities, and compress genetic diversity.

2. Climate change - Biodiversity and climate change are strongly linked. Although the climatehaschanged constantly throughout Earth's history with the development and extinction of ecosystems and species, accelerated climate change is disrupting ecosystems and the species' ability to acclimatize, increasing biodiversity loss. Rapid climate change stimulates the loss of biodiversity, endangering human interests and the safety of clean water, air, medicine, and additional natural resources on which we depend. Climate change, among other components, such as habitat loss, land degradation, hunting, over-exploitation of certain species, etc., is becoming a major threat to the biodiversity. Allegations of sudden climate change are often corroborated by a variety of extinction statistics on species that until recently were part of biodiversity.

3. Natural disasters - Natural disasters, such as volcanoes, fires, floods, hurricanes, drafts, epidemics, tsunamis, etc. cause great loss of biodiversity. In humid tropical areas such as central Africa, eastern and northern Australia, some areas in South America, floods are common. Tropical areas have a lot of vegetation, and a huge number of animals survive in the vegetation. Due to flooding, large amounts of nutrients are leached from the soil. Drought has also led to dry soil and decrease of the water levels. Both animals and plants suffer in this situation.

4. Pollution - Air pollution affects the respiratory system of animals and adversely affects their well-being, including the ability to lay eggs and changes in behaviour. Air pollution is also known to affect the reproductive ability of animals and hence breeding failure. The indirect impact of air pollution on animals is difficult to assess because it is difficult to investigate in a controlled environment. Water pollution has a detrimental effect on biodiversity. Synthetic fertilizers usually contain nitrogen and phosphorus and they are added to soil to increase crop productivity. Nitrogen and phosphorus are removed from the soil to water bodies or groundwater. The presence of these nutrients in the water leads to eutrophication or the overgrowth of plants. Eutrophication causes a decrease in oxygen levels in waters which is harmful to biodiversity. Fish and other aquatic animals die due to a lack of dissolved oxygen in the water. Just like fertilizers, pesticides can also accumulate in water bodies. Pesticides adversely affect running water bodies such as lakes and ponds since fertilizers are not washed off and aquatic animals have difficulty in reproduction. Environmental microplastics also affect larval survival, reduced food intake, and gradual weight loss in aquatic animals, which eventually leads to their extinction. Soil pollution is another factor that negatively affects biodiversity. Heavy metal contaminated soil greatly affects the well-being of microorganisms necessary to sustain the life of soil organisms. Excess heavy metals present in the soil do not decompose easily and accumulate from plants (Singh et al., 2021). Immense use of fertilizers, pesticides, and antibiotics used in agriculture is very harmful to biodiversity. The increased presence of nutrients in the soil causes a vigorous growth of grass species, which leads to the suppression of the growth of wildflowers, necessary for bees and other pollinating insects.

5. Hunting - Hunting is the leading cause of the extinction of many animals in the food chain. Because of this, different species in certain regions are adversely affected as they face food shortages or complete inaccessibility of food compared to the normal state. Hunting is a major operator for biodiversity loss. Hunting activities carry a significant burden on wildlife, causing a huge decline in wildlife and leading to disrupted and inefficient ecosystems. Unsustainable collection of aromatic and medicinal herbs and mushrooms also harms biodiversity. The mushrooms used for consumption are present in only certain regions and their excessive and uncontrolled collection may lead to their non-appearance in the next season. There are many examples where whole forests are devastated by wild collectors of 
medicinal plants.

6. Excessive exploitation - Excessive exploitation of species from their natural habitat in higher numbers than they can reproduce new species. Currently, almost one-third of the Earth's vertebrates that are facing extinction are vulnerable to overexploitation. Extreme fishing and hunting are examples of over-exploitation. Similarly, various animals and plants are collected for use as pets, trophies, or souvenirs.

\section{Biodiversity conservation}

The loss of flora and fauna due to human activities has been going on for millennia, but only recently have we begun to understand the consequences of this loss for structure and function of ecological systems at the biome scale and the Earth system (Murray, 2017). Although relevant biodiversity conservation factors increasingly recognize the need to restore and conserve entire systems, their priorities and interventions remain focused on scales that are too small to address the functions of the biome or the system as a whole. It is constantly argued that a new global initiative is needed to address the past and current loss of flora and fauna and its functional units.

According to Brütting et al. (2013) there are generally two conservation approaches of existing biodiversity: 1 . in situ and 2. ex situ conservation:

1. In situ - an approach that includes methods and tools that protect species, genetic varieties, and habitats in their natural habitats. It is a favourable approach among environmentalists for the protection of habitats and ecosystems.

2. Ex situ - an approach that includes methods that remove plants, animals and microbiological species, and genetic varieties from their natural habitat. These methods are popular with agronomists and biologists and help maintain species populations.

Restoration and rehabilitation approaches include methods that rely on in situ and ex situ tools to re-establish species, genetic varieties, communities, populations, habitats, and ecological processes. Ecological regeneration usually involves the reconstruction of natural and semi-natural ecosystems on degraded lands. This includes the reintroduction of most indigenous species, while ecological rehabilitation involves repairing ecosystem processes.

\section{In situ conservation}

It is a dynamic way of preserving germplasm compared to the static nature of ex situ conservation. Allows continuous evolution of cultures by allowing natural selection to act on it. Lately, in situ conservation has been attracting a lot of attention and efforts are being made to preserve genetic resources under its natural environment. It is important to preserve species that are difficult to preserve in an extra situation. In situ conservation involves maintenance of genetic variation in the location where it occurs, either in the wild or in traditional farming systems (Fig. 7).

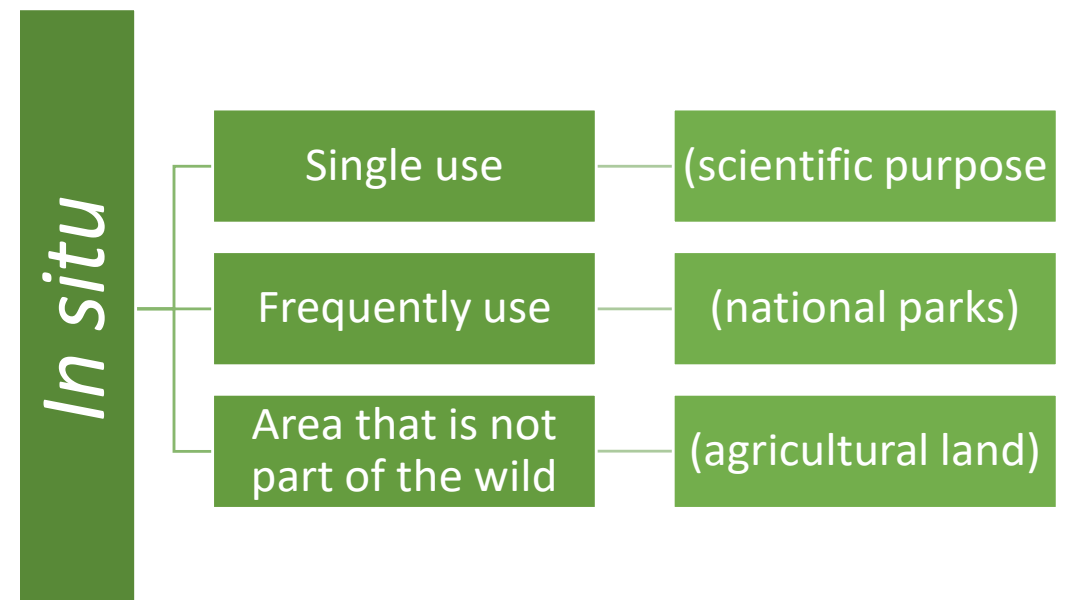

Figure 7. In situ methods of biodiversity conservation (adapted from Zegeye, 2016). 
Wildlife conservation includes the location, designation, management, and monitoring of genetic diversity at a specific, natural site. This technique is most suitable for most wildlife species, as it can be relatively inexpensive when management is minimal. Genetic variation present in wild plant populations is a necessary condition for evolutionary adaptation to the changing environment and hence the survival of the species. Genetic variation is therefore essential for maintaining a sustainable population. To establish a genetic reserve for the target taxon or group, the effective population size must be assessed. Genetic reserves are suitable for orthodox seeds, i.e. seed types that can be maintained in long-term storage with a combination of moisture content reduction and low-temperature storage and unorthodox seeds, i.e. seed types that cannot be stored for a long time. Genetic reserves also allow multiple storages of the taxon in a single reserve and allow continuous evaluation of the species. However, the disadvantages are that the stored material is not immediately available for human exploitation, and if the management mode is minimal, little characterization or assessment data may be available.

Modern breeding methods have largely taken the place of traditional farming methods, leading to the loss of many old varieties. It is necessary to preserve the diversity found in both wild relatives and old varieties of domestic species. Farm preservation involves maintaining traditional cropping systems or growing by farmers within traditional farming systems. The advantage of preserving the farm is that it provides landscaping and those wild species dependent on traditional agriculture. However, yields may be lower than their contemporary successors and may be less popular within farmers. Therefore, some form of motivation, even subsidies, associated with regular monitoring may be needed to ensure sustainability. Home garden conservation is a variant of farm preservation. It involves growing a variety of materials in homes, backyards, or gardens and focuses on growing food crops, medicinal plants, herbs, and spices grown primarily for home consumption. Although the individual sizes of such gardens are likely to be small, genetic safety can be achieved by agglomerating neighbouring households. Home gardens are often the source of traditional varieties lost from larger agricultural systems. It should be noted that modern economic forces will tend to act against the continuous maintenance of old varieties, and they undoubtedly currently suffer from rapid genetic erosion, therefore, a developed system of ex situ conservation is necessary.

\section{Ex situ conservation}

Ex situ conservation is a technique of conserving all levels of biodiversity outside their natural habitats through various techniques such as zoos, aquariums, botanical gardens, and gene banks (Borokini et al., 2010). It plays a key role in communicating problems, raising awareness, and gaining broad public and political support for conservation and breeding activities of endangered species (Fig. 8).

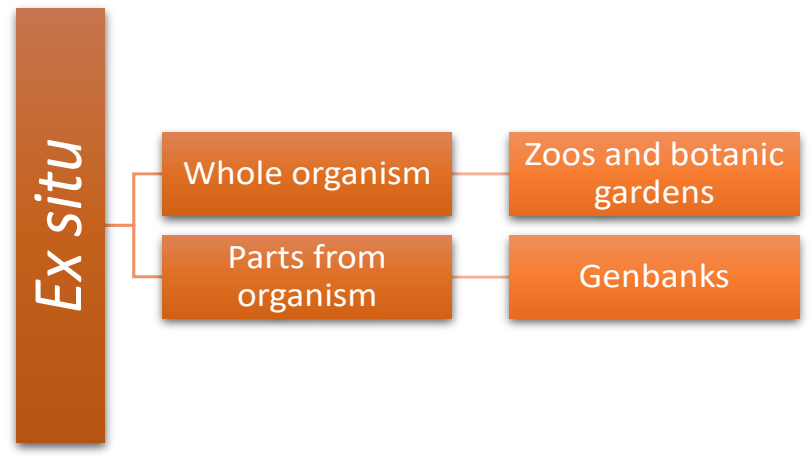

Figure 8. Ex situ types of conservation (adapted from Zegeye, 2016).

Limitations of ex situ conservation include keeping organisms in artificial habitats, deteriorating genetic diversity, inbreeding depression, captivity adjustments, and accumulation of harmful alleles. Currently, several stakeholders are actively working on biodiversity conservation through ex situ conservation strategies through the establishment of gene banks, botanical gardens, and zoos (Zegeye, 2016). 


\section{Zoos}

Zoos are places where animals are confined to cages or semi-natural and open areas, displayed to the public and in which they can also breed. They are considered important means of preserving biodiversity. Zoos attract as many as 450 million visitors each year and are therefore uniquely positioned to have very high educational and economic value (Carrizo et al., 2013). Zoos not only act as places for entertainment and observation of animal behaviour but also institutions, museums, research laboratories, and information banks for rare animals, as well as domestic animals. Over the last few decades, zoos have made significant progress in the cooperative management of ex situ populations, both of wild and indigenous animal.

\section{Botanical gardens}

Botanical gardens consist of plants, grown outdoors or in greenhouses. They are used to grow and display plants primarily for scientific and educational purposes (Waylen, 2006). They also include herbariums, laboratories, libraries, museums, and experimental or research plantations. They can contain a certain family, genus, or group of varieties, natural plants, wild relatives, medicinal, aromatic, or textile plants. There are over 2,000 botanical gardens that have 80,000 plant species in their collections and receive hundreds of millions of visitors a year. Furthermore, they have a valuable and distinctive mix of staff dedicated to plant research, systematics, conservation education and raising the public awareness. They are extremely well networked with each other and with other professionals, conservation organizations, and NGOs (Blackmore et al., 2011). They provide a variety of services to sectors that use and preserve plant diversity, such as agriculture, forestry, pharmaceutical, and biofuels industry, protected area management and ecotourism, and have a unique opportunity to attract visitors and scientific institutions to document and preserve plant diversity through shaping and mobilizing citizens towards current environmental challenges. Botanical gardens allow cultivated plants to be grown under relatively modified environmental conditions (intensive cultivation, relatively high fertility, and high levels of disturbance).

\section{Genbanks}

Genbanks are biological repositories that aim to preserve genetic material. In plants, it can be by freezing parts of plants or storing seeds, and in animals by freezing sperm or eggs in specially designed refrigerators with a certain temperature. The main purpose of the existence of gene banks is to preserve genetic diversity, which would help in future research and the formation of new species (Clarke, 2009). They exist to preserve the wild and cultural species on which humans depend. In addition to the genetic resource, there is information about that organism. They represent the gene pool which is actually the basis of all genes contained in a particular seed. The size of the gene pool directly affects the evolutionary path of that species. Cryobanks are ex-situ gene banks. In this way, cultivated plants, plants for medicinal purposes, or endangered species are preserved. Avocados, papaya, coffee, and walnuts have seeds that cannot withstand low temperatures, and all those protocols are needed for conventional seed gene banks and therefore are stored cryogenically. The Russian Academy of Sciences preserves 7 varieties of strawberries and raspberries that must also be cryogenically preserved, 250 endangered species from Russian territory, and 20 plants of pharmaceutical importance. In this way, fruit crops, tropical and subtropical fruits are preserved. Their seeds are placed in bottles with liquid nitrogen and they are frozen and their vital functions are stopped until they are thawed. In humans and animals, this is applied by freezing sperm in special ampoules. In vitro tissue and organ culture techniques gives possibilities whole organs or part of plant tissues (buds, rhizomes, meristematic tissue) to be multiplied in identical plants (clones) with the same characteristics as the parental plant. 


\section{CONCLUDING REMARKS}

Agrobiodiversity is a basic resource in agricultural production and offers a wide selection of species, varieties, populations and genotypes. All processes that take place in the process of food production are directly or indirectly related to agrobiodiversity. Biodiversity, in addition to the numerous benefits to agriculture, is part of many industries and provides raw materials. Apart from the direct benefits, it offers us many regulatory, cultural and social benefits in all spheres of life. Taking in consideration all above presented, we can drove certain conclusions related to importance and role of agrobiodiversity in sustainable agriculture:

Agriculture is one of the main drivers of positive and negative changes in biodiversity, both in plants and animals. Agroecosystems can be the biggest promoters of biodiversity, but also the biggest destructive force.

The principles and techniques applied in agricultural production determine the direction of movement of changes in plant and animal populations.

Soil fertility is a reflection of soil biodiversity, which is composed of thousands of micro- and macroorganisms. On the other hand, soil fertility is directly related to the yield and health of plants.

A key moment in agriculture is pollination and many crops are dependent on entomophile pollination. The biodiversity of insect pollinators provides security and stability in the agroecosystem.

Population of beneficial insects in and near agroecosystems optimizes the control of weeds and economically harmful insects. A proper management of beneficial insects and their attraction brings numerous benefits for an agroecosystem.

Organic food production is based on the use of biodiversity and maximization of natural processes in the environment, as well as achieving high yields. The symbiosis of agrobiodiversity and human activities offers the organic farming as an example for rational use of land resources without experiencing negative consequences for any of the parties involved in the process.

Agrobiodiversity offers practical applicable solutions for management with extremely rapid manifestations of nature, which negatively affect the growth and development of crops. Agrobiodiversity ensures yields at specific times.

Agriculture shall promote and balance biodiversity at the same time together with application of certain agricultural practices. Proper application of cultivation techniques as crop rotation, sideration, buffer belts, animal manure utilization, biological control and cover crops provides higher yields in the current cultivation season. Moreover, it contributes to balanced ecosystems with long-term positive effect on cultivation. Application of those practices increases the biological activity in the soil, improves organic matter content, raises the populations of beneficial insects, and reduces the need for application of chemical inputs.

The loss of biodiversity is a direct consequence of human activities on Earth. The loss refers to reduction in the number of individuals in a population or the complete extinction of a species. The extinction of the species affects the stability of the food chains and negatively affects the agricultural production, particularly when certain species or varieties with potential to cope extreme conditions are lost.

Biodiversity conservation is key to successfully tackling environmental change. The principles of biodiversity conservation are commonly known as in situ and ex situ. It is particularly important all measures for prevention of loss of some species to be undertaken. The local farmers who grow indigenous varieties in their gardens also contribute to this preservation, as well as different institutions that intentionally conserve the genetic resources with various approaches.

Overall, the biodiversity, in addition of being able to intensify agricultural production, is an inseparable integral element of any agroecosystem. It is important to emphasize that the methods and principles applied in agriculture should be moderate, balanced and appropriate to the current situation in the systems. Techniques that invoke modern intensive production, including the use of any synthetic inputs, genetically modified plants, or overuse of resources, can have a negative long-term effect on biodiversity. Of utmost importance are all efforts to conserve and preserve biodiversity from its extinction. 


\section{REFERENCES}

Barling, R. D., \& Moore, I. D. (1994). Role of buffer strips in management of waterway pollution: a review. Environmental management, 18(4), 543-558.

Bélanger, J., \& Pilling, D. (2019). The state of the world's biodiversity for food and agriculture. Food and Agriculture Organization of the United Nations (FAO).

Benton, T. G., Vickery, J. A., \& Wilson, J. D. (2003). Farmland biodiversity: is habitat heterogeneity the key?. Trends in ecology \& evolution, 18(4), 182-188.

Blackmore, S., Gibby, M., \& Rae, D. (2011). Strengthening the scientific contribution of botanic gardens to the second phase of the Global Strategy for Plant Conservation. Botanical Journal of the Linnean Society, 166(3), 267-281.

Borokini, T. I., Okere, A. U., Daramola, B. O., \& Odofin, W. T. (2010). Biodiversity and conservation of plant genetic resources in the Field Genebank of the National Centre for Genetic Resources and Biotechnology, Ibadan, Nigeria. International Journal of Biodiversity and Conservation, 2(3), 037-050.

Brookfield, H., \& Stocking, M. (1999). Agrodiversity: definition, description and design. Global Environmental Change-human and Policy Dimensions - GLOBAL ENVIRON CHANGE.

Brütting, C., Hensen, I., \& Wesche, K. (2013). Ex situ cultivation affects genetic structure and diversity in arable plants. Plant Biology, 15(3), 505-513.

Carrizo, S. F., Smith, K. G., \& Darwall, W. R. T. (2013). Progress towards a global assessment of the status of freshwater fishes ( $P$ isces) for the IUCN R ed $L$ ist: application to conservation programmes in zoos and aquariums. International Zoo Yearbook, 47(1), 46-64.

Clarke, A. G. (2009). The Frozen Ark Project: the role of zoos and aquariums in preserving the genetic material of threatened animals. International zoo yearbook, 43(1), 222-230.

Cleveland, D. A., Soleri, D., \& Smith, S. E. (1994). Do folk crop varieties have a role in sustainable agriculture? Incorporating folk varieties into the development of locally based agriculture may be the best approach. BioScience, 44(11), 740-751.

Culliney, T. W., \& Pimentel, D. (1986). Ecological effects of organic agricultural practices on insect populations. Agriculture, ecosystems \& environment, 15(4), 253-266.

Darwish, O. H., Persaud, N., \& Martens, D. C. (1995). Effect of long-term application of animal manure on physical properties of three soils. Plant and soil, 176(2), 289-295.

Delaplane, K. S., Mayer, D. R., \& Mayer, D. F. (2000). Crop pollination by bees. Cabi.

Dudley, N., \& Alexander, S. (2017). Agriculture and biodiversity: a review. Biodiversity, 18(2-3), 45-49.

FAO (2005). Training Manual "Building on Gender, Agrobiodiversity and Local Knowledge".

Francis, F., Haubruge, E., Hastir, P., \& Gaspar, C. (2001). Effect of aphid host plant on development and reproduction of the third trophic level, the predator Adalia bipunctata (Coleoptera: Coccinellidae). Environmental Entomology, 30(5), 947-952.

Frankel, O., \& Soulé, M. E. (1981). Conservation and evolution. CUP Archive.

Giller, K. E., Beare, M. H., Lavelle, P., Izac, A. M., \& Swift, M. J. (1997). Agricultural intensification, soil biodiversity and agroecosystem function. Applied soil ecology, 6(1), 3-16.

Gomiero, T., Pimentel, D., \& Paoletti, M. G. (2011). Environmental impact of different agricultural management practices: conventional vs. organic agriculture. Critical reviews in plant sciences, 30(1-2), 95-124.

Harris, J. (2001). Millennium ecosystem assessment. SER Europe Summer School, September 2007.

Hasan, H. A. H. (2000). Ureolytic microorganisms and soil fertility: A review. Communication in soil science and plant analysis, 31(15-16), 2565-2589.

Henis, Y. (1986). Soil microorganisms, soil organic matter and soil fertility. In The role of organic matter in modern agriculture (pp. 159168). Springer, Dordrecht.

Hossain, S., Bergkvist, G., Glinwood, R., Berglund, K., Mårtensson, A., Hallin, S., \& Persson, P. (2015). Brassicaceae cover crops reduce Aphanomyces pea root rot without suppressing genetic potential of microbial nitrogen cycling. Plant and Soil, 392(1), 227-238.

Institute of Biodiversity Conservation (IBC) (2005). National Biodiversity Strategy and Action Plan. Government of the Federal Democratic Republic of Ethiopia, Addis Ababa, 103. 
Isbell, F., Craven, D., Connolly, J., Loreau, M., Schmid, B., Beierkuhnlein, C., ... \& Eisenhauer, N. (2015). Biodiversity increases the resistance of ecosystem productivity to climate extremes. Nature, 526(7574), 574-577.

Jarvis, D. I., Hodgkin, T., Sthapit, B. R., Fadda, C., \& Lopez-Noriega, I. (2011). An heuristic framework for identifying multiple ways of supporting the conservation and use of traditional crop varieties within the agricultural production system. Critical Reviews in Plant Sciences, 30(1-2), 125-176.

Khaliq, A., Javed, M., Sohail, M., \& Sagheer, M. (2014). Environmental effects on insects and their population dynamics. Journal of Entomology and Zoology studies, 2(2), 1-7.

Ma, M., Tarmi, S., \& Helenius, J. (2002). Revisiting the species-area relationship in a semi-natural habitat: floral richness in agricultural buffer zones in Finland. Agriculture, ecosystems \& environment, 89(1-2), 137-148.

Maxted, N., \& Guarino, L. (2006). Genetic erosion and genetic pollution of crop wild relatives. In Genetic erosion and pollution assessment methodologies. Proceedings of PGR Forum Workshop (Vol. 5, pp. 35-45).

Mazid, M., \& Khan, T. A. (2015). Future of bio-fertilizers in Indian agriculture: an overview. International Journal of Agricultural and Food Research, 3(3).

Meilink, W. R., Arntzen, J. W., van Delft, J. J., \& Wielstra, B. (2015). Genetic pollution of a threatened native crested newt species through hybridization with an invasive congener in the Netherlands. Biological Conservation, 184, 145153.

Mellon, M. G., Benbrook, C., \& Benbrook, K. L. (2001). Hogging it: estimates of antimicrobial abuse in livestock. Union of Concerned Scientists.

Murray, B.G. (2017). Plant diversity, conservation and use. Editor(s): Brian Thomas, Brian G Murray, Denis J Murphy. Encyclopedia of Applied Plant Sciences (Second Edition), Academic Press, 2017, pp. 289-308.

Odum, E. P., \& Kuenzler, E. J. (1955). Measurement of territory and home range size in birds. The Auk, 72(2), 128-137.

Pal, K. K., \& Gardener, M. B. (2006). Biological control of plant pathogens. The Plant Health Instructor DOI, 10.

Petersen, H., \& Luxton, M. (1982). A comparative analysis of soil fauna populations and their role in decomposition processes.
Oikos, 288-388.

Pimentel, D., Huang, X., Cordova, A., \& Pimentel, M. (1997). Impact of population growth on food supplies and environment. Population and environment, 9-14.

Price, A. J., Stoll, M. E., Bergtold, J. S., Arriaga, F. J., Balkcom, K. S., Kornecki, T. S., \& Raper, R. L. (2008). Effect of cover crop extracts on cotton and radish radicle elongation. Communications in biometry and crop science, 3, 60-66.

Rader, R., Bartomeus, I., Garibaldi, L. A., Garratt, M. P., Howlett, B. G., Winfree, R., ... \& Woyciechowski, M. (2016). Non-bee insects are important contributors to global crop pollination. Proceedings of the National Academy of Sciences, 113(1), 146-151.

Rodriguez, H., \& Fraga, R. (1999). Phosphate solubilizing bacteria and their role in plant growth promotion. Biotechnology advances, 17(4-5), 319-339.

Schowalter, T. D. (2019). Insects and sustainability of ecosystem services. CRC Press.

Convention on Biological Diversity (2008). Convention on biological diversity. pp. 72.

Singh, V., Shukla, S., \& Singh, A. (2021). The principal factors responsible for biodiversity loss. Open Journal of Plant Science, 6(1), 011-014.

Snapp, S. S., Swinton, S. M., Labarta, R., Mutch, D., Black, J. R., Leep, R., ... \& O'neil, K. (2005). Evaluating cover crops for benefits, costs and performance within cropping system niches. Agronomy journal, 97(1), 322-332.

Stork, N. E. (2018). How many species of insects and other terrestrial arthropods are there on Earth?. Annual review of entomology, 63, 31-45.

USDA (2000). Organic Production/Organic Food: Information Access Tools. Retrieved from https://www.nal.usda.gov/afsic/organicproductionorganic-food-information-accesstools\#define

Underwood, E., \& Tucker, G. (2016). Ecological Focus Area choices and their potential impacts on biodiversity. Report for BirdLife Europe and the European Environmental Bureau.

Underwood, T., McCullum-Gomez, C., Harmon, A., \& Roberts, S. (2011). Organic agriculture supports biodiversity and sustainable food production. Journal of Hunger \& Environmental Nutrition, 6(4), 398-423. 
Vasić, M., Milošević M., Savic, A., Stojanovic, A., Nikolic, Z., Terzić, S., Gvozdanović-Varga, J., ... Popovic, V. (2013). Očuvanje agrobiodiverziteta kao šansa za održivi i ruralni razvoj. Zbornik referata 47. savetovanje agronoma Srbije.

Watson, C. A., Atkinson, D., Gosling, P., Jackson, L. R., \& Rayns, F. W. (2002). Managing soil fertility in organic farming systems. Soil use and management, 18, 239-247.

Waylen, K. (2006). Botanic gardens: using biodiversity to improve human wellbeing. Medicinal Plant Conservation, 12, 4-8.

Zegeye, H. (2016). In situ and ex situ conservation: complementary approaches for maintaining biodiversity. International Journal of Research in Environmental Studies. 4. 1-12.
Илиева, В. (2012). Селекција на растенијата. Универзитет „Гоце Делчев“ Штип.

Колева Гудева, Л., Михајлов, Љ., Трајкова, Ф. (2012). Агроекологија. Универзитет „Гоце Делчев" - Штип.

Михајлов, Љ. (2013). Органско производство - интерна скрипта. Универзитет „Гоце Делчев" - Штип.

\title{
УЛОГАТА И ЗНАЧАЊЕТО НА АГРОБИОДИВЕРЗИТЕТОТ ЗА ЗЕМЈОДЕЛСТВОТО
}

\author{
Фиданка Трајкова ${ }^{1}$, Сашо Арсов ${ }^{1}$, Лилјана Колева Гудева' \\ 'земјоделски факултет, Универзитет „Гоче Делчев“ - Штип, Крсте Мисирков, 10-A, 2000 Шmun, \\ Република Северна Македонија \\ *Контакт автор: fidanka.trajkova@ugd.edu.mk
}

\section{Резиме}

Биодиверзитетот и земјоделството имаат нераскинлив однос со меѓусебно зависни интеракции меѓу нивните составни компоненти. Земјоделството како основна антропогена активност е еден од главните фактори во насоките на развој во биодиверзитетот. Агробиодиверзитетот е основата на постоењето на процесите на производство на храна и обезбедува и осигурува многу есенцијални елементи од современото живеење. Многу од тие процеси се целосно непознати, а за некои од нив не сме свесни дека се последица на биолошката активност на разните организми. Па така, биодиверзитетот обезбедува храна, чиста вода за пиење, енергија, суровини за индустријата, туристички и рекреативни можности, научни истражувања и лекови. Доколку се користат земјоделски практики кои го промовираат биодиверзитетот, како на пример: плодоред, покривни растенија, буферни појаси, употреба на биопестициди, корисни инсекти и меѓупосеви, тогаш природните процеси во почвата, растенијата и животната средина значително се интензивираат во корист на земјоделците, растенијата и целокупната животна средина. Од другата страна, доколку се применуваат техники и методи кои го редуцираат биодиверзитетот во агроекосистемот и неговата околина како вештачки ѓубрива, хемиски пестициди, хормони, интензивна обработка, монокултурно одгледување и други, настапуваат процеси на редуцирање, исчезнување и загадување на животната средина и целокупниот биодиверзитет. Затоа е потребен внимателен избор на земјоделски практики кои не би го загрозиле опстанокот на видовите, а истовремено ќе се постигнат високи приноси со добар квалитет.

Целта на овој прегледен труд е да се презентираат односите меѓу биодиверзитетот и земјоделството и да се истакнат актуелните прашања за губењето на биодиверзитетот и методите за негова конзервација.

Клучни зборови: генетски ресурси, автохтони сорти, агробиодиверзитет, органско производство, одржливо земјоделство, заштита, конзервација. 